KREATIF : Jurnal Ilmiah Prodi Manajemen Universitas Pamulang, Volume 8, No. 1, Juni 2020

KREATIF

Jurnal Ilmiah

Prodi Manajemen Universitas Pamulang
ISSN : $2339-0689$, E-ISSN : 2406-8616

J. KREATIF, Vol. 8, No.1, Juni 2020 (Halaman 124-137)

Tersedia Online di: http://openjournal.unpam.ac.id/index.php/kreatif

\title{
KEPEMIMPINAN DAN KOMUNIKASI PENGARUHNYA TERHADAP KINERJA DENGAN KEPUASAN KERJA SEBAGAI VARIABEL INTERVENING
}

\author{
Nurmin Arianto, ${ }^{1 *}$ Lilis Suryani $^{2}, *$ Asep Sulaeman $^{3}$ \\ ${ }^{1-3}$ Program Studi Manajemen Fakultas Ekonomi Universitas Pamulang \\ email: dosen 01118@unpam.ac.id
}

\begin{abstract}
ABSTRAK
Sekolah menjadi sebuah kebutuhan yang mendasar bagi semua orang maka dari itu seorang guru dituntut untuk dapat memberikan pengajaran terhadap peserta didik dan hal ini dipengaruhi oleh kepemimpinan dan komunikasi serta kepuasan kerja Guru yang berakibat terhadap kinerja guru tersebut, maka dari itu tujuan diadakan penelitian ini adalah untuk mengetahui bagaimana pengaruh baik secara parsial atau simultan variabel independen dan dependen serta mengetahui bagaimana pengaruh variabel mediator.

Penelitian ini bersifat deskriptif kuantitatif dengan jumlah populasi yang digunakan dalam penelitian ini adalah 40 Guru yang mengajar disekolah tersebut dan teknik sample yang digunakan adalah sampel jenuh, sedangkan teknik analisis data dalam penelitian ini dengan menggunakan menggunkan analisis jalur.

Dari hasil penelitian yang dilakukan sebagain besar guru yang ada disekolah adalah laki-laki dengan usia $36-45^{\text {th }}$ dan lulusan S1. Dari tanggapan responden bahwa kepemimpinan, komunikasi dan kepuasan kerja serta kinerja yang ada disekolah sudah baik walaupun masih terdapat beberapa keluhan guru, namun dari hasil analisis bahwa kepemimpinan, komunikasi dan kepuasan kerjan memiliki pengaruh terhadap kinerja serta kepemimpinan dan komunikasi memiliki pengaruh terhadap kepuaan kerja, sehingga kepuasan kerja dapat menjadi mediator dalam mempengaruhi kepemimpinanan terhadap kinerja dan kepuasan kerja dapat menjadi mediator dalam mempengaruhi komunikasi terhadap kinerja.
\end{abstract}

Kata Kunci: Kepemimpinan, Komunikasi, Kepuasan, Kinerja

\section{ABSTRACT}

Schools become a fundamental need for all people and therefore a teacher is required to be able to provide teaching to students and this is influenced by leadership and communication and job satisfaction of teachers that affect the teacher's performance, and therefore the purpose of this research is to know how to influence both partially or simultaneously independent and dependent variables and know how to influence the mediator variables.

This research is quantitative descriptive with the number of population used in this study is 40 teachers who teach at the school and the sample technique used is saturated sample, while the data analysis technique in this study uses path analysis.

From the results of research conducted by most of the teachers in the school are men aged 36-45 years and graduates S1. From the responses of respondents that leadership, communication and job satisfaction as well as the performance in schools are good although there are still some teacher complaints, but the results of the analysis that leadership, communication and job satisfaction have an 
influence on performance and leadership and communication have an influence on work age, so job satisfaction can be a mediator in influencing leadership on performance and job satisfaction can be a mediator in influencing communication on performance.

Keywords: Leadership, Communication, Satisfaction, Performance

\section{PENDAHULUAN}

\section{Latar Belakang}

Sekolah menjadi kebutuhan mendasar bagi semua orang, apalagi dijaman yang semakin mengedepankan pendidikan sebagai salah satu tolok ukur dan penilaiannya ini. Sekolah dianggap sebagai rumah kedua untuk mendapatkan pendidikan setelah pendidikan pertama didapat melalui rumah dan orang tua. Sekolah bisa diartikan sebagai tempat didikan bagi anak anak yang tujuannya adalah mengajarkan anak agar mampu untuk memajukan bangsa, sekolah diartikan pula sebagai sebuah lembaga yang dirancang untuk mengajar siswa dibawah pengawasan guru. Kepemimpinan merupakan tulang punggung pengembangan organisasi, karena tanpa kepemimpinan yang baik akan sulit untuk mencapai tujuan organisasi.

Dalam dunia pendidikan tidak terlepas dari kepemimpinan dan kegiatan komunikasi. Mereka dapat menggunakan berbagai media komunikasi yang ada, baik konvensional maupun yang elektronik sebagai sarana penyimpanan pesan pesan.

Dibawah ini dapat dilihat poin-poin penilaian mengenai peran kepemimpinan dan komunikasi guru disekolah selama 3 tahun terakhir :

Tabel 1.1

PoinPenilaian Kepeminpinan Dan Kommikasi Guru

\begin{tabular}{|c|c|c|c|c|c|}
\hline \multirow[b]{2}{*}{ No } & \multirow[b]{2}{*}{ Keterangan } & \multicolumn{4}{|c|}{ Tahum } \\
\hline & & Bobot & $2014 / 2015$ & $2015 / 2016$ & $2016 / 2017$ \\
\hline \multicolumn{6}{|c|}{ Kepemimpinan } \\
\hline 1 & $\begin{array}{l}\text { Menciptakan suasana yang } \\
\text { harmonis dilinghungan sekolah }\end{array}$ & 20 & $20 \%$ & $17 \%$ & $14 \%$ \\
\hline 2 & $\begin{array}{l}\text { Monitoring dan mendengar secara } \\
\text { efektif }\end{array}$ & 20 & $20 \%$ & $18 \%$ & $20 \%$ \\
\hline & TotalProsentase & 40 & $40 \%$ & $35 \%$ & $34 \%$ \\
\hline \multicolumn{6}{|c|}{\begin{tabular}{cc|c} 
TotalProsentase & 40 \\
& Kormunikasi \\
\end{tabular}} \\
\hline 3 & $\begin{array}{ll}\text { Kemampuan } & \text { kormunikasi } \\
\text { interpersonal } & \end{array}$ & 20 & $16 \%$ & $20 \%$ & $19 \%$ \\
\hline 4 & Menciptakan suas ana kondus if & 20 & $20 \%$ & $17 \%$ & $16 \%$ \\
\hline 5 & Memotivasi paraguru lain & 20 & $18 \%$ & $20 \%$ & $19 \%$ \\
\hline & TotalProsentase & 60 & $54 \%$ & $57 \%$ & $54 \%$ \\
\hline
\end{tabular}

Berdasarkan data tersbut mempngaruhi perunanan penurunan kinerja guru hal ini sejalan dengan penelitian yang di lakukan oleh Lilis (2012), Indah (2017), Ainur (2018), Kiswanto (2010) yang menyatakan bahwa kepemiminan memiliki pengaruh terhadap kinerja. Selain itu jika dilihat pada tabel data point Penilaian Komunikasi Guru dan dari data tersebut maka dapat diketahui komunikasi yang terjadi berakibat terhadap kinerja hal ini sejalan dengan penelitia yang di lakukan oleh Lilis (2012), Indah (2017), Ainur (2018), Kiswanto (2010) yang menyatakan bahwa komunikasi memiliki pengaruh terhadap kinerja, Berdasarkan data tersebut maka dapat di ketahui terjadi penurunan kinerja guru hal ini bisa disebabkan langsung oleh kepuasan guru terhadap pekerjaan yang dijalankanya dimanan kepuasan kerja tergantung kesesuaian atau keseimbangan antara yang diharapkan dengan kenyataan, Kepuasan kerja yang tinggi akan membuat guru semakin loyal 
terhadap sekolah, semakin termotivasi untuk bekerja, hal tersebut disebabkan karena pemimpin mengerti dan memahami apa yang dibutuhkan para guru.

Slah satu indikator yang mempengaruhi kpuasan krja adalah Upah yng didapat guru berdasarkan jam mengajar di sekolah tersebut dimana disajikan dalam tabel berikut ini :

Tabel 1.3 Gaji GuruTidak Tetap Yayasan

\begin{tabular}{|c|c|c|}
\hline Keterangan & Jam Menzajar & Total \\
\hline $\begin{array}{c}\text { Jumlah Jam Menzajar } \\
\text { Tertinggi }\end{array}$ & 30 Jam x Rp. 27.000 & Rp. 810.000 \\
\hline $\begin{array}{c}\text { humlah Jam Menzajar } \\
\text { Terendar }\end{array}$ & 12 Jam x Rp. 27.000 & Rp. 324.000 \\
\hline
\end{tabular}

Dari tabel diatas maka dilihat bahwa gaji guru perjam nya di bayar sebanayak Rp. 27.000 dan rata-rata jam mengajar untuk satu bulan berkisar antara 12-30 Jam untuk setiap guru.sehingga gaji disekolah tersbeuut berkisar anatara Rp.342.000- Rp. 810.000, dengan gaji sekecil itu masa kondisi ekonomi yang terpuruk saat ini, gaji tersebut tidak memenuhi kebutuhan hidup guru sehari-hari, oleh karena itu sebagian guru memiliki temat mengaar lain dan memiliki usaha sampingan, dan secara tidak langsung banyak guru yang merasa masih kurang puas dengan pekerjaan yang dijalankanya sehingga menyebab kepuasan kerja menurun, dan dampaknya terhadap kinerja guru, hal ini sejalan dengan penelitian Oxy (2018), Ivan (2018), Gary (2017), Risky (2018), Ayu (2013) yang menyatakan bahwa kepuasan kerja berpengaruh terhadap kinerja selain itu juga kinerja guru

Komunikasi mendukung terciptanya semangat kerja yang tinggi yang dapat dilihat dari kedisplinan guru termasuk didalamnya kehadiran, yang digunakan untuk menyelesaikan suatu pekerjaan dan juga kontribusi yang dapat dia berikan kepada sekolah tempat dia bekerja. Serta kepuasan kerja yang di rasakan oleh guru dalam mengerjakan pekerjaanya sebgaia tenaga pengajar dan hal ini salah satunya dapat dilihat dari laporan absensi guru,

Tabel 1.2

Absensi Guru

\begin{tabular}{|c|c|c|c|c|c|c|}
\hline \multirow{2}{*}{ Tahum } & \multirow{2}{*}{$\begin{array}{c}\text { Jumlah } \\
\text { Guru }\end{array}$} & \multicolumn{4}{|c|}{ Absensi } & \multirow{2}{*}{$\begin{array}{c}\text { Jumlah } \\
\text { Absensi }\end{array}$} \\
\cline { 3 - 7 } & Persentase & Ijin & Apha & \\
\hline $2014 / 2015$ & 40 & 11 & 8 & 4 & 23 & $0,2 \%$ \\
\hline $2015 / 2016$ & 40 & 5 & 14 & 15 & 34 & $0,4 \% \%$ \\
\hline $2016 / 2017$ & 40 & 6 & 24 & 22 & 52 & $0,5 \%$ \\
\hline
\end{tabular}

menunjukan hasil absensi pada kehadiran guru selama 3 tahun terakhir,dimana tabel ini menjelaskan bahwa keterangan jumlah absensi guru tertinggi terjadi pada tahun ajaran periode $2016 / 2017$ sebanyak 52 , dan dalam persenan mencapai $0,5 \%$, dapat dilihat bahwa tingkat kehadiran guru pada Sekolah semakin menurun, yang mana hal tersebut sengat berpengaruh pada kinerja guru. Jika kinerja guru tidak maksimal, maka tujuan sekolah pun tidak akan tercapai secara optimal,namun sebaliknya apabila kinerja guru optimal maka tujuan sekolah pun akan tercapai. Dengan latar belakang pembahasan yang telah diuraikan diatas,penulis ingin membahas seberapa jauh pengaruh kepemimpinan dan komunikasi terhadap kinerja guru khususnya dalam meningkatkan kinerja guru, maka penulis tertarik untuk meneliti dengan judul yan diangkat dalam penelitian ini adalah "Kepemimpinan dan Komunikasi Pengaruhnya Terhadap Kinerja dengan Kepuasan Kerja Sebagai Variabel Intervening". 


\section{LANDASAN TEORI Kepemimpinan}

Menurut Gary Yukl (2015:9) kepemimpinn adlah proses memengaruhi orang lain untu memhami dan menyetujui apa yang dibutuhkan dalm melaksanakan tugas dan bagaimana melakukan tugas itu, serta proses untuk memfasilitasi upaya individu dan kolekftif guna mencapai tujuan brsama.

Dapat dinyatakan bahwa kepemimpinan merupakan suatu usaha dari seseorang pemimpin untuk dapat merealisasikan tujuan individu atau pun tujuan organisasi. Oleh karena itu, pemimpin diharapkan dapat memengaruhi, mendukung, dan memberikan motivasi agar para pengikutnya tersebut mau melaksanakannya secara antusias dalam mencapai tujuan yang diinginkan baik secara individu maupun organisasi. Sedangkan Indikator yang di gunakan untuk mengukur kepemimpinan adalah Gary Yukl (2010:67), sebagai berikut : Visioner, Pembimbing, Afiliatif ( menggabungkan), Demokratis, Komunikatif

\section{Komunikasi}

Menurut Fieske (2012:1) komunikasi adalah salah satu dari aktivitas manusia dan suatu topik yang amat sering diperbincangkan sehingga kata komunikasi itu sendiri memiliki arti beragam. Komunikasi memiliki variasi definisi dan rujukan yang tidak terhingga seperti: saling berbicara satu sama lain, televisi, penyebaran informasi, gaya rambut kita, kritik sastra, dan masih banyak lagi. Indikator yang digunakan mengukur Komunikasi menurut Popy Ruliana (2014:21) diantaranya adalah Proses (Process), Pesan (Message), Jaringan ( Network), Keadasaan saling tergantung (Interdependence), Hubungan (Relationship)

\section{Kepuasan Kerja}

Kepuasan kerja merupakan perasaan pegawai terhadap pekerjaannya, apakah senang / suka atau tidak senang / tidak suka sebagai hasil interaksi pegawai dengan lingkungan pekerjaannya atau sebagai presepsi sikap mental, juga sebagai hasil penilaian pegawai terhadap pekerjaannya. Priansa (2014:291). Sedangakan indicator yan digunakan utuk mengukur kepusan kerjan mnurut Robbins ( 2015: 181-182): Pekerjaan yang secara mental menantang, Kondisi kerja yang mendukung, Gaji atau upah yang pantas, Kesesuaian kepribadian dengan pekerjaan, Rekan sekerja yang mendukung.

\section{Kinerja}

Kinerja guru menurut Supardi (2014:54) kinerja guru merupakan kemampuan seorang guru dalam melaksanakan tugas pembelajaran di madrasah dan bertanggung jawab atas peserta didik dibawah bimbingannya dengan meningkatkan prestasi belajar peserta didik. Oleh karena itu, kinerja guru itu dapat diartikan sebagai suatu kondisi yang menunjukan kemampuan seorang guru dalam menjalankan tugasnya di madrasah serta menggambarkan adanya suatu perbuatan yang ditampilkan guru dalam atau selama melakukan aktivitas pembelajaran. Indikator yang di gunakan untuk megukur Kinerja menurut Supardi didalam bukunya (2014:70) yaitu Kuantitas pekerjaan, Kualitas pekerjaan, Inisiatif dalam kerja, Kemampuan beradaptasi, Kerja sama. 


\section{METODE PENELITIAN \\ Populasi dan Sampel}

Populasi dalam penelitian ini adalah guru yang berjumlah 40 Guru dari tahun 2014 sampai tahun 2017. Artinya penelitian ini melibatkan seluruh populasi sehingga sampel sama dengan populasi

Dan penelitian ini menggunakan non probblity sampling adalah Teknik pengambilan sample yang tidak memberikan peluang atau kesempatan sama baik setiap unsur atau anggota populasi untuk dipilih menjadi sample, Sugiyono (2015:218), sehingga metode yang digunakan adaah metode sampel jenuh. Menurut Sugiyono (2015:85) sampling jenuh adalah teknik penentuan sampel bila semua anggota populasi digunakan sebagai sampel. Berdasarkan pada tempat penelitian yang telah ditetapkan, maka sampel yang dijadikan objek dalam penelitian ini adalah seluruh guru yang mengajar disekola yang berjumlah 40 orang.

\section{Teknik Pengumpulan Data}

Pada penelitian ini penulis menggunakan pengumpulan data dengan cara penelitian lapangan yang terdiiri dari Obervasi Non Partisipan dan Kuisioner Tertutup serta studi kepustakaan dimana peneliti mendpaatkan informasi dari buku dan internet.

\section{Analisis Data}

Adapuan untuk analisis data penulis menggunakan uji isntrumen yang terdiri dari Uji Validitas dan Uji Reliabilitas serta Uji Asumsi Klasik.

Sedangkan metode analisis data yang di gunakan dalam penelitian ini menggunakan analisisJalur

\section{HASIL DAN PEMBAHASAN \\ Uji Instrumen}

\section{a. Uji Validitas}

Dari hasil perhitungan dimana variabel kempimpinan, komunikasi dan kepuasan serta kinerja guru diperoleh nilai $r$ hit $>$ dari 0,30, maka semua item kuesioner dinyatakan valid. Untuk itu kuesioner yang digunakan layak untuk diolah sbagai data penelitian, hal ini sejalan dengan pendapat Sugiyono (2013:182).

\section{b. Uji Relibilitas}

Dari hasil perhitungan dimana variabel kepemimpinan, komunikasi dan kepuasan serta kinerja guru dnyatakan reliabel, hal itu dibuktikan dengan masing -masing variabel memiliki nilai coeficien Alpha lebih besar dari Chronbath Alpha 0,60. Hal in isejalan dengan teori dari Sugiyono (2013:184) yang mengatakan bahwa syarat minimal uji realibilitas adalah jika nilai Rca nya 0,60 .

\section{Uji Asumsi Klasik}

Dari hasil analisis data maka data dikatakan normal, tidak terjadi multikolinieritas dan tidak terjadi heteroskedastisitas.

\section{HASIL PENELITIAN}

\section{Analisis Deskriptif Karakteristik Responden}

Dari hasil penyebaran kuisioner maka diketahui bahwa jenis kelamin guru yang mengajar mayoritas adalah Laki dengan jumlah 28 guru atau 70\%. Sedangkan berdasarkan usia maka mayoritas guru berusia 36-45 th yaitu 14 guru atau 35\% 
sedangakan berdasarkan Pendidikan mayoritas gurur berpendidikan S1 yaitu sebanyak 25 guru ata $62,5 \%$.

\section{Anlisis Deskriptif Variabel}

\section{Kepemimpinan}

Tanggapan responden atas pernyataan pada variabel kepemim pinan diperoleh rata-rata skor 4,09 term a sukpada rentangsk ala 3,40-4,19 dengankriteria baik, dan dibuktik an dari skor tertingg pada pernyataan no 10 yaitu sebesar 4,18 dim ana Kepala sekolah tidak m embeda-bedakan di dalam betkom urikasi dengan gun bant dan gunulam a, sehingga halini m em berikan kenyam ankepada gunu-gund. Disam pingitu tm asih terdapat skorrendr yaitu sebesar 3,75 pada pernyataan no 1 dim ana "Berpikir ke depan tentang masa depan sekolah (visioner)". Dim ana masih terdapat responden yangm enyatakantidak setuju dikarenakan terkadangkepala sekolahj arangberpikir untuk kedepan nya dalam mengambil keputusan, maka dari itu sebaaiknya kepala sekolah harus lebih m emikitkan saran ataum asukan dari Gunt-guru lainya sehingga tidak mudah dalam m engambil keputusan terlebih terkait masa depan sekolah

\section{Komunikasi}

Tanggapan responden pada variabel kom urikasi diperoleh rata-rata skor 4.06 term ask pada rentang skala 3,40-4,19 dengan kriteria baik, dan dilihat dari skor tertinggi pada pernyataanno 10 yaitu sebesar 4,20, dim ana gunu-gunu m engajak dan m engarahkan m urid nya untuk m engikuti kegatan orgarisasi seperti Volley, Futsal, Marawis danOsis. Disam pingitu m asih terdapat skor rendar yaitu sebesar 3,75 pada pernyataan no 5 diam ana "Kepala sekolah m em beri pesan tertulis kepada guru yang tidak masuk" dari hasil obervasi dilapangan m asih terdapat guru yang m enyatakan bahwa kepala sekolah kurangberkomunikasi denganguru terlebih tentang guru yang tidak m asuk, jika ada gunuyangtidak m asuk dalam $1-2$ harikepala sekolah tidak m em anggil guru ybs dan memberi sangsi, m elaikan m engabaikarya, sebaaiknya kepala sekolah harus lebih tegas m enyampaikan inform asi kepada guru yang tidak m asuk sekolah dan m enyakan ala sanya agar tidak terjadikesalapahaman

\section{Kepuasan}

Tanggapanrespondenpada varia bel $\mathrm{Kepuasan}$ diperoleh rata-rata skor 3,87 term asuk pada rentang skala 3,40-4,19 dengan kriteria baik, dan dilihat dari skor tertingg pada pernyataan no 1 dengan skor 4,15, dim ana para guru-guru m erasa puas dengan dengan peluangkerja yang diberikan untuk depat menyeleaiakan pekerjaan dariawal sam pai akhir. Selain itu tm asih terdapat guruyang kurang puas karena masih terdapat sk or rendahyaitu sebesar 3,58 pada pernyataan no 2 "Saya m enyukai pekerjaan yang m enggunakan ketreampilan" hal ini m enandakan m asih terdapat gun yangkurangm enyukaia pekerjaan yangm enggunakan keterampilan karena m asih a da guru yang harus m engajar tidak sesuai dengan gelar pendidikanyang di peroleh nya, th aka dari itu sebaik nya kepala sekolahm em buatja dwal m ata pelajaran sesua dengan keahlian dan keterampilan yang dimiliki oleh guru-guru.

\section{Kinerja}

Tanggapan responden variabel kinerja guru beragam, diperoleh rata-rata skor sebesar 4.00 term a suk pada rentang sk ala 3,40-4,19 dengankriteria baik, dan dibuktikandari skor tertingg pada pernyataan no 4 yaitu sebesar 4,13 dim ana kepala sekola sudah $m$ em berikan dorongan dan m otivasi yang baik sehingga m eningkatkan kinerja gund. Disisilain $m$ asih terdapat skor rendah yaitu sebesar 3,80 pada pernyataanno 5 diam an Guru harus m empunyaikesadaransendiri untik m asuk tepat waktu, dari ha sil penyebaran kuisioner m a sih terapat guru-guruyangbelom seperuh nya menyadari untuk $m$ asuk tepata waktukarena $m$ asih a da guru-guru yang datangterlam bat dan m enyelesaik an tugasyangterlam bat, m aka dari itu sebaik nya kepala sek ola harus bertindak tegas terhadap guru-guru yaang tidak tepat waktu dengan m em otong gaji nya sesusai dengan jam keterlam batanya.

Anaısis verimkauı 
Analisis verifikatif dimaksudkan untuk mengetahui besaran pengaruh dan menganalisis signifikansi dari perngaruh tersebut..

a. Uji Statistik

Menurut B awono (2006), uji statistikdigunakan untuk m elihat tingakya ketetapan atau kakuratan dari sautu fungsi atau persam aan untuk m enaksir dari data yang di analisis Nilai ketepanatau keaktuala ini dapat diuku dari goodness off fit nva. Ui statistic ini dapat dilihat dari nilai t hitung dan Fhitung dan koefisein determnasinya.Uji statistic dikatakanllos atau tidaknya tergantung dari tingkat signifikanya dari ha sil perhitungan tersebut. Jika hasil berada di daerahkritis atau yangm enolak $\mathrm{H}$ om aka dikatakan bahwa uji statistiknya lols dan lavak untuk di uji selanjutny darini berlakujika didaerahH o.

1) $\mathrm{Uji} \mathrm{T}$ Test

Uji ini dilakkan untuk m elihat tingakt signifikanvariabl independerlm empengandhi variable depnden secara individu atau sendiri-sendiri, pengujian ini dilakukan secara individual atau parsial dengan uji statistic untuk m a sing-m asing variable

\section{Hasil Uji T test}

Kepemimpianan, Komunikasi dan Kepuasan-Kinerja

Coefficients

\begin{tabular}{|c|c|c|c|c|c|c|}
\hline \multirow{2}{*}{\multicolumn{2}{|c|}{ Model }} & \multicolumn{2}{|c|}{ Unstandardized Coefficients } & \multirow{2}{*}{$\frac{\text { Standardized Coefficients }}{\text { Beta }}$} & \multirow{2}{*}{$t$} & \multirow{2}{*}{ Sig. } \\
\hline & & $\mathrm{B}$ & Strl. Error & & & \\
\hline \multirow{4}{*}{1} & (Constant) & 11.63 & 5.329 & & 2.182 & 0.036 \\
\hline & Kepernimpinan & 0.237 & 0.133 & 0.442 & 2.967 & 0.005 \\
\hline & Komurikasi & 0.247 & 0.132 & 0.385 & 2.638 & 0.002 \\
\hline & Kepuasan & 0.236 & 0.193 & 0.441 & 3.359 & 0.002 \\
\hline
\end{tabular}

a. Dependent Variable: Kinerja

Berdasarkantable diatas maka dapat disim pulkan bahwa:

a) Kepem im pinan m em punyai nilai t sebsar 2,967 dan nilai signifikansi 0,005 $<0,05$, halini berati bahwa nilai $2,967>2,026$ dan $0,005<0,05$ yangberati bahwa kepemim pinanm emiliki pengaruh yang positif dansignifikan tethadap kinerja.

b) Kom unikasi m empunyai nilai t sebesar 2,638 dan nilai signifikansi yaitu0,012 sehingga $2,638>2,026$ dan $0,002<0,05$ yang berarti bahwa kom urikas m em iliki pengaruh yangpositif dan signifikanterhadap kinerja.

c) Kepuasan m emiliki nilai t sebesar 3,359 dan nilai signfikansi 0,002 sehing $3,359>2,026$ dan $0,002<0,05$ maka kepuasanm emiliki penganuhyang positf dan signifikan terhadap kinerja.

\section{Hasil Uji T test}

Kepemimpianan, Komunikasi-Kepuasan

\begin{tabular}{|c|c|c|c|c|c|c|}
\hline \multicolumn{7}{|c|}{ Coefficients ${ }^{2}$} \\
\hline \multirow{2}{*}{\multicolumn{2}{|c|}{ Mode1 }} & \multicolumn{2}{|c|}{ UnstandardizedC oefficients } & \multirow{2}{*}{$\frac{\text { StandardizedC oefficients }}{\text { Beta }}$} & \multirow{2}{*}{$t$} & \multirow{2}{*}{ Sig } \\
\hline & & $\mathrm{B}$ & Std. Error & & & \\
\hline \multirow{3}{*}{1} & (Constant) & 33.057 & 7.695 & & 4.296 & 0 \\
\hline & Kepem im pinan & 0.524 & 0.226 & 0.34 & 2.659 & 0.003 \\
\hline & Kom unikasi & 0.668 & 0.229 & 0.211 & 2.305 & 0.001 \\
\hline
\end{tabular}

a. Dependent Variable: Kepuasan 
d) Kepemimpinan mempunyai nila $\mathrm{t}$ sebsar 2,659 dan nilai signifikansi $0,003<0,05$, hal ini berati bahwa nilai $2,659>$ 2,026 dan $0,003<0,05$ yang berati bahwa kepemimpinan memiliki pengaruh yang positif dan signifikan terhadap kepuasan kerja.

e) Komunikasi mempunyai nila $\mathrm{t}$ sebsar 2,305 dan nilai signifikansi $0,001<0,05$, hal ini berati bahwa nilai 2,305> 2,026 dan $0,001<0,05$ yang berati bahwa komunikasi memiliki pengaruh yang positif dan signifikan terhadap kepuasan.

2) Uji Ftest

Uji $F$ dilakukan guna mengetahui seberaa jauh semua variable $X$ secara bersama-sama dpaat mmpengaruhi variable $\mathrm{Y}$.

Hasil Uji T test

Kepemimpianan, Komunikasi-Kepuasan

\begin{tabular}{|c|c|c|c|c|c|}
\hline \multicolumn{6}{|c|}{ ANOVA* } \\
\hline Model & Sum of Squares & df & Mean Square & $F$ & $\mathrm{SiR}$ \\
\hline 1 Reptessicn & 259,000 & 3 & 86.333 & 14878 & 000 \\
\hline Residual & 208.900 & 36 & 5.803 & & \\
\hline Total & 467900 & 39 & & & \\
\hline
\end{tabular}

Adapun penjelasan mengenai hasil uji $\mathrm{F}$ yang telah disajika pada table diatas bahwa nilai $\mathrm{F}$ hitung 14,878 dengan nilai signifikansi 0,000. Hal ini menunjukan bahwa 14,878 > 2,859 dan 0,000 < 0,05 yang arti nya secara simultan variable kepemimpinan, komunikasi dan kepuasan kerja memiliki pengaruh terhadap kinerja secara postif dan signifikan.

3) Uji Determinasi

Koefiisien determinasi menunjukan sejauh manan tingkat hubungan antara variable Dependen dengan variable Independen . pengujian ini melihat $\mathrm{R}^{2}$ pada hasil analisis persamaan regresi yang diperoleh, apabila angka koefisien determinasi semakin mendekati angka 1 maka model regresi yang dignakan sudah semakin tetap sebagai model penduga terhadap variable Dependen.

\begin{tabular}{|c|c|c|c|c|}
\hline \multicolumn{5}{|c|}{$\begin{array}{l}\text { Hasil Uji Koefisien Determinasi } \\
\text { Model Sumunary }\end{array}$} \\
\hline Model & $\bar{R}$ & R. Square & Adjustol R square & Sd Error of the Estimate \\
\hline 1 & $744^{*}$ & 554 & ST6 & 2409 \\
\hline
\end{tabular}

Berdasarkan table diatas maka diketahui nilai koefisien korelasi $\mathrm{R}$ sebesar 0,744, hal tersebut menunjuka ada nya hubungan yang Kuat antara variable independen dengan dependen. Sedangkan nila koefisien determinasi $\mathrm{R}^{2}$ yaitu 0,554 yang menjelaskan bahwa variable independen berkontribusi mempengaruhi variable dependen sebesar 55,4\% dan sisanya 44,6\% dijelaskan oleh variable lain diluar penelitian yang sedang dijalankan ini. Dan nilai koefisien Adjusted (Adj R2) sehingga lebih mendekati populasi.

4) Uji Path Analsis 
Untuk m enguji pngaruh variable intervning digunakan m etode analisis $j$ alur yang m erpakan perluasan dari analisis regresi linier berganda atau analisi jalur adalah pengquna an analisis regresi untuk th enaksir hubungan kausalitas antar variable (m odecausal) yangtelah ditetapkan sebelumnya berdasarkante ori danm enentukan pola hubungan antara tiga / lebih vriable dan tidak dapat digunakan untuk m enokonfirm asi atau m enolak hipotesis(Ghazali, 2013:249).

Berdasarkan table 4.15 . dan 4.16 kemudin m enghasilkan m del analsis jalur seperti

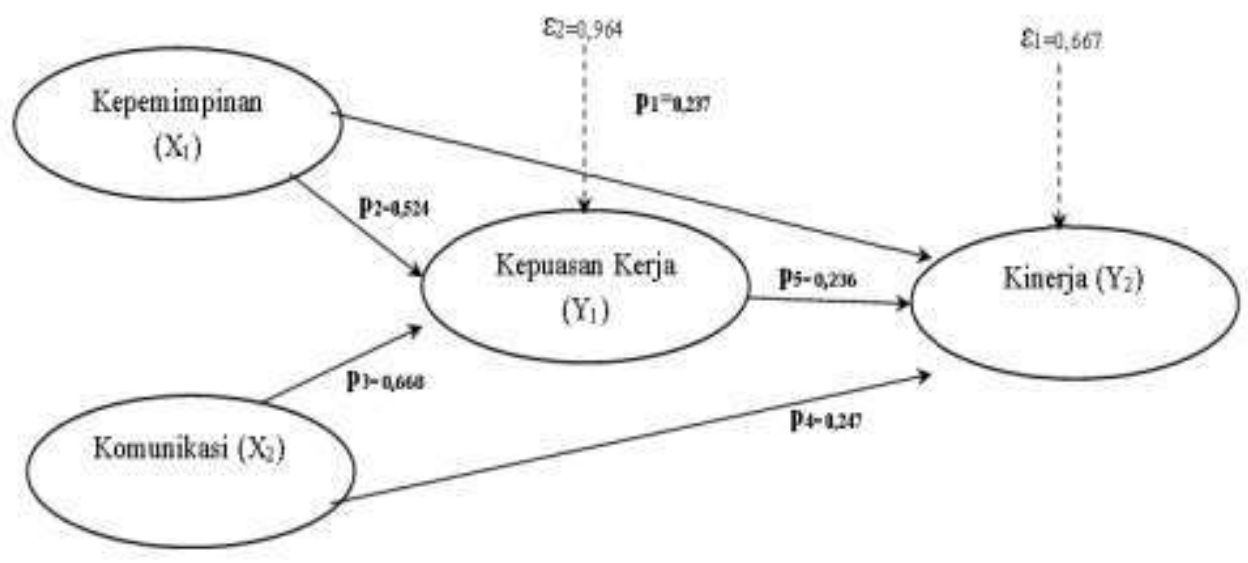

Hasil Uji T test

Kepemimpianan, Komunikasi dan Kepuasan-Kinerja

Coefficients ${ }^{2}$

\begin{tabular}{|c|c|c|c|c|c|}
\hline \multirow[t]{2}{*}{ Model } & \multicolumn{2}{|c|}{ Unstandardized Coefficients } & \multirow{2}{*}{$\begin{array}{c}\begin{array}{c}\text { Standardized } \\
\text { Coefficients }\end{array} \\
\text { Beta }\end{array}$} & \multirow[t]{2}{*}{$\mathrm{t}$} & \multirow[t]{2}{*}{ Sig. } \\
\hline & B & Std. Error & & & \\
\hline (Constant) & 11.63 & 5.329 & & 2.182 & 0.036 \\
\hline Kepemimpinan & 0.237 & 0.133 & 0.442 & 2.967 & 0.005 \\
\hline Komunikasi & 0.247 & 0.132 & 0.385 & 2.638 & 0.002 \\
\hline Kepuasan & 0.236 & 0.193 & 0.441 & 3.359 & 0.002 \\
\hline
\end{tabular}

a. Dependent Variable: Kinerja

Hasil Uji T test

Kep emimpianan, Komunikasi-Kepuasan

Coefficients $s^{2}$

\begin{tabular}{|l|r|r|r|r|r|}
\hline \multirow{2}{*}{ Model } & \multicolumn{2}{|c|}{ Unstandardized Coefficients } & \multicolumn{1}{c|}{$\begin{array}{c}\text { Standardized } \\
\text { Coefficients }\end{array}$} & \multirow{2}{*}{ t } & Sig. \\
\cline { 2 - 6 } & $\mathrm{B}$ & Std. Error & Beta & & \\
\hline \multirow{2}{*}{ (Constant) } & 33.057 & 7.695 & & & 0 \\
1 Kepemimpinan & 0.524 & 0.226 & 0.34 & 2.659 & 0.003 \\
Komunikasi & 0.668 & 0.229 & 0.211 & 2.305 & 0.001 \\
\hline
\end{tabular}

a. Dependent Variable: Kepuasan 
Hasil Uji Koefisien Determinasi

Model Summary

\begin{tabular}{|c|c|c|c|c|}
\hline Model & $\mathrm{R}$ & $\begin{array}{c}\mathrm{R} \\
\text { Square } \\
\end{array}$ & $\begin{array}{l}\text { Adjusted R } \\
\text { Square }\end{array}$ & $\begin{array}{l}\text { Std. Error of the } \\
\text { Estimate }\end{array}$ \\
\hline 1 & $.744^{\mathrm{a}}$ & .554 & .516 & 2.409 \\
\hline \multirow{2}{*}{\multicolumn{5}{|c|}{$\begin{array}{l}\text { a. Predictors: (Constant), Kepuasan, Komunikasi, Kepemimpinan } \\
\qquad e 2=\sqrt{1-r 2}\end{array}$}} \\
\hline & & & & \\
\hline & & & $e 2=0,667$ & \\
\hline
\end{tabular}

Model Summaryb

\begin{tabular}{|c|c|c|c|c|}
\hline Model & R & R Square & $\begin{array}{c}\text { Adjusted R } \\
\text { Square }\end{array}$ & $\begin{array}{c}\text { Std. Error of } \\
\text { the Estimate }\end{array}$ \\
\hline 1 & $.263^{\mathrm{a}}$ & .069 & .019 & 4.258 \\
\hline
\end{tabular}

a. Predictors: (Constant), Komunikasi, Kepemimpinan

b. Dependent Variable: Kepuasan

$$
\begin{gathered}
\Theta 1=\sqrt{1-r^{2}} \\
\epsilon 1=\sqrt{1-0,069} \\
\epsilon 1=0,964
\end{gathered}
$$

Berda sarkan gambar diatas dapat dikethaui penganuh langgungatau tidak langoung sert pengandh total daripenelitian inivaitu:

1) Penganuhlangsungkepemimpinan terhadapkinerja (p1) $=0,237$

2) Penganh tidak langgungkepemim pinan terhadapkinerja

$p_{2} \times p s=0,524 \times 0,236=0,123664$

Maka pengaruhtidaklanggung antara $X_{1}$ ke $Y$ sebesar 0,123664

3) Penganuh totalkepemim pian terhadapkinerja

Pengaruh langsung + pengaruh tidak langrung

$=p_{1}+\left(p_{2} \times p s\right)=0,237 \times 0,123664=0,0293308368$

4) Pengaruh totalkom urikasi terhadapkinerja $(\mathrm{p} 4)=0,247$

5) Pengaruh tidak langgungkomunikasi terhadap kinerja $p 3 \times p 5=0,668 \times 0,236=0,157648$ Mka pengaruh anatara $\mathrm{X}_{2} \mathrm{ke} Y$ Sebesar 0,157648

6) Pengaruh total kom urikasi terhadapkinerja Pengaruh langgung + pengaruh tidak langgung= $=p_{4}+\left(p_{3} \times p 5\right)$ $=0,247+0,157648=0,404648$ Makapengaruhtotal $\mathrm{X}_{2} \mathrm{keY}$ sebesar 0,404648

Untuk m engetahu tingkat m ediasi variabel kepuasan kerja terhadap kinerja dan kom unikas terhadapkinerja m aka standar error darikoefisienindirecteffect dpat dinyatakana:

1) $\mathrm{Sp} 2 \mathrm{Sp} 5=\sqrt{p 5^{2} s p 2^{2}+p 2^{2} s p 5^{2}+s p 2^{2} s p 5^{2}}$

$$
\begin{aligned}
& \text { Sp2Sp5 }=\sqrt{(0,236)^{2} \cdot(0,226)^{2}+(0,524)^{2} \cdot(0,193)^{2}+(0,226)^{2} \cdot(0,193)^{2}} \\
& \text { Sp2Sp5 }=\sqrt{(0,002844729)+(0,010227681)+(0,00190253)} \\
& \text { Sp2Sp5 }=\sqrt{0,01497494} \\
& \text { Sp2Sp5 }=0,122372137
\end{aligned}
$$


2) $\mathrm{Sp} 3 \mathrm{p} 5=\sqrt{p 5^{2} s p 3^{2}+p 3^{2} s p 5^{2}+s p 3^{2} s p 5^{2}}$

Sp3Sp5 $=\sqrt{(0,236)^{2} \cdot(0,229)^{2}+(0,668)^{2} \cdot(0,193)^{2}+(0,229)^{2} \cdot(0,193)^{2}}$

Sp3Sp5 $=\sqrt{(0,002920754)+(0,016621398)+(0,001953375)}$

Sp3Sp5 $=\sqrt{0,021495527}$

Sp3Sp5 = 0,0144613529

Berdasarkan hal diatas maka dapat diperoleh nilai t satistik pengaruh mediasi sebagai berikut:

1) $\mathrm{t}_{1}=\frac{\mathrm{p} 2 \mathrm{p} 5}{s p 2 p 5}=\frac{0,524 * 0,236}{0,226 * 0,236}=2,318584071=2,319$

2) $t_{2}=\frac{p 3 p 5}{S p 3 p 5}=\frac{0,668 * 0,236}{0,229 * 0,236}=2,917030568=2,917$

Dengan m elihat sem ua sem ua pengukuran ditas m aka sdapat ditarik kesim pulan sebagai berikut:

1) Karena thitung sebesar 2,319 dan t tabel 2,026 dengan niai signifikansi 0,05 , m aka dapat disim pulkan bahwa koefisein mediasi sebesar 0,0293308368 signifikan yang berati kepuasan dapat m eriadi m ediator dalam pengaruhkepemimpinanan terhadapkinerja.

2) Karena thitug sebesar 2,917 dan t tabel 2,026 denga nilai signfikansi 0,05 , maka dapat disim pulkan koefisien m ediasi sebesar 0,404648 yangberatikepuasankerja dapat m erjadi m ediator dalam pengaruhkomurik asi terhadap kinerja.

\section{PEMBAHASAN}

a. Hasil uji hipotesis 1 (Kepemimpinan berpengaruh signifikan terhadap kinerja) Variabel kepemimpinan memiliki nilai standardized coefficients sebesar 0,442 dan tingkat significant sebesar 0,005 pada koefisien alpha 5\%. Dari hasil tersebut menunjukan bahwa tingkat significant kurang dari 5\% atau $0,005<$ 0,05. Maka artinya terdpaat pengaruh signifikan antara kepemimpinan (X1) terhadap kinerja (Y). Yang dapat ditarikpengertian tiapkenaiakan variabel kepemimpinan $1 \%$ maka akan menaikan 44,2\% tingkat kinerja. Hal ini sejalan dengan penelitian yang dilakukan oleh Lilis (2012), Moh. Ainur (2018), Kiswanto (2010) dan penelitian ini juga bertolak belakanag dengan penelitian Indah (2017) yang menyatakan kepemimpinan tidak memilikipengaruh terhadap kinerja.

b. Hasil uji hipotesis 2 (Komunikasi berpengaruh signifikan terhadap kinerja) : Variabel komunikasi memiliki nilai standardized coefficients sebesar 0,385 dan tingkat significant sebesar 0,002 pada koefisien alpha 5\%. Dari hasil tersebut menunjukan bahwa tingkat significant kurang dari $5 \%$ atau $0,002<0,05$. Maka artinya terdapaat pengaruh signifikan antara komunikasi $\left(\mathrm{X}_{2}\right)$ terhadap kinerja (Y). Yang dapat ditarik pengertian tiap kenaiakan variabel komunikasi $1 \%$ maka akan menaikan 38,5\% tingkat kinerja. Kesimpulan ini sependapat dengan penelitian yang dilakukan oleh Lilis (2012), Indah (2017), M. Ainur (2018), Kiswanto (2010).

c. Hasil uji hipotesis 3 (Kepemimpinan berpengaruh signifikan terhadap Kepuasan) : Variabel kepemimpinan memiliki nilai standardized coefficients sebesar 0,340 dan tingkat significant sebesar 0,003 pada koefisien alpha 5\%. Dari hasil tersebut menunjukan bahwa tingkat significant kurang dari 5\% atau $0,003<0,05$. Maka artinya terdapat pengaruh signifikan antara kepemimpinan $\left(\mathrm{X}_{1}\right)$ terhadap kepuasan $(\mathrm{Z})$. Yang dapat ditarik pengertian tiap kenaiakan variabel Kepemimpinan 1\% maka akan menaikan 34,0\% tingkat kepuasan. Kesimpulan ini sependapat dengan penelitian yang dilakukan oleh Rifqy (2018), Delisius (2018), Makararung (2018) dan Yanti (2019) serta Bertolak belakangan dengan penelitian Rachmand (2013). 
d. Hasil uji hipotesis 4 (Komunikasi berpengaruh signifikan terhadap kepuasan) : Variabel komunikasi memiliki nilai standardized coefficients sebesar 0,211 dan tingkat significant sebesar 0,001 pada koefisien alpha 5\%. Dari hasil tersebut menunjukan bahwa tingkat significant kurang dari $5 \%$ atau $0,001<0,05$. Maka artinya terdapaat pengaruh signifikan antara komunikasi $\left(\mathrm{X}_{2}\right)$ terhadap kepuasan (Z). Yang dapat ditarik pengertian tiap kenaiakan variabel komunikasi $1 \%$ maka akan menaikan 21,1\% tingkat Kepuasan. Kesimpulan ini sependapat dengan penelitian yang dilakukan oleh . Kesimpulan ini sependapat dengan penelitian yang dilakukan oleh Rifqy (2018), Delisius (2018), Makararung (2018) dan Yanti(2019).

e. Variabel kepuasan memiliki nilai standardized coefficients 0,441 dan tingkat significants 0,002 pada koefisien alpha sebesar 5\%. Dengan hasil tersebut menunjukan bahwa tingkat signficant kurang dari $5 \%$ atau $0,002<0,05$. Yang artinya terdapat pengaruh signifikan antara kepuasan $(\mathrm{Z})$ terhadap kinerja $(\mathrm{Y})$. Yang dapat ditarik kesimpulan tiap kenaiakn 1\% variabel kepuasan maka akan menaikan 44,1\% kinerja. Kesimpulan ini sependapat dengan penelitian yang dilakukan oleh Oxy (2018), Iwan (2018), Garry (2017), Risky (2018), Ayu (2013).

f. Variabel kepuasan dengan dimediasi mempunyai nilai t hitung sebesar 2,319 lebih besar dari t tabel yaitu 2,026 dengan tingkat signifikansi 5\%, maka dapat disimpulkan bahwa koefisien mediasi sebesar 0,0293308368 seignifikan yang berarti ada pengaruh memediasi. Yang berati kepuasan dapat memediasi pengaruh kepemimpinan terhadap kinerja dengan pengaruh positif dan signifikan. Variabel komunikasi dengan dimediasi kepuasan mempunyai nilai $t$ hitung sebesar 2,917 lebih besar dari t tabel 2,026 dengan tingkat singfikansi 5\% maka dapat disimpulkan bahwa koefisien mediasi sebesar 0,404648 signifkana yang berarti adal pengaruh mediasi. Yg berrti kepuasan kerja dapat memdiasi pengruh komunikasi terhdap kinrja dengan pngaruh yang psitif dan signfikan

\section{PENUTUP}

\section{Kesimpulan}

hasil penelitian dan pembahasan yang telah dikemukakn $\mathrm{p}$ maka dapat ditarik kesimpulan sebagai berikut:

1. Dari hasil pengujian $t$ test menunjukan kepemimpinan berpengaruh positif dan sigifikan terhadap kinerja.

2. Dari hasil pengujian $t$ test menunjukan komunikasi berpengaruh positif dan sigifikan terhadap kinerja.

3. Dari hasil pengujian $t$ test menunjukan kepemimpinan berpengaruh positif dan sigifikan terhadap kepuasan.

4. Dari hasil pengujian t test menunjukan komunikasi berpengaruh positif dan sigifikan terhadap kepuasan.

5. Dari hasil pengujian $t$ test menunjukan kepuasan berpengaruh positif dan sigifikan terhadap kinerja.

6. Dengan melakaukan pengujian menggunakan analisis jalur (path analisi) menunjukan bahwa kepemimpinan berpengaruh langsung psositif dan signfikan terhadap kinjera dengan dimediasi oleh kepuasan. Dan hasil pengujisi dengan menggunakan analisis jalur (path analisis) menunjukan bahwa komunikais 
berpengaruh lansung positif dn signfiikan terhadapkinerja dengan dimediasi oleh kepuasan.

\section{Saran}

1. Sebaaiknya kepala sekolah harus lebih memikirkan saran atau masukan dari Guru-guru lainya sehingga tidak mudah dalam mengambil keputusan terlebih terkait masa depan sekolah.

2. Hasil observasi dilapangan masih terdapat guru yang menyatakan bahwa kepala sekolah kurang berkomunikasi dengan guru terlebih tentang guru yang tidak masuk, jika ada guru yang tidak masuk dalam 1-2 hari kepala sekolah tidak memanggil guru ybs dan memberi sangsi, melaikan mengabaikanya, sebaaiknya kepala sekolah harus lebih tegas menyampaikan informasi kepada guru yang tidak masuk sekolah dan menyakan alasanya agar tidak terjadi kesalapahaman.

3. Masih terdapat guru yang kurang menyukai pekerjaan yang menggunakan keterampilan karena masih ada guru yang harus mengajar tidak sesuai dengan gelar pendidikan yang di peroleh nya, maka dari itu sebaik nya kepala sekolah membuat jadwal mata pelajaran sesua dengan keahlian dan keterampilan yang dimiliki oleh guru-guru.

4. Masih terapat guru-guru yang belom sepenuh nya menyadari untuk masuk tepata waktu karena masih ada guru-guru yang datang terlambat dan menyelesaikan tugas yang terlambat, maka dari itu sebaik nya kepala sekola harus bertindak tegas terhadap guru-guru yaang tidak tepat waktu dengan memotong gaji nya sesusai dengan jam keterlambatanya.

\section{DAFTAR PUSTAKA}

A Muwafik Saleh. 2010. Manajemen Pelayanan. Pustaka Pelajar, Jakarta. 2010.

Ayu Desi Indrawati. 2013. Pengaruh Kepuasan Kerja Terhadap Kinerja Karyawan Dan Kepuasan Pelanggan Pada Rumah Sakit Swasta Di Kota Denpasar. Jurnal Manajemen, Strategi Bisnis, Dan Kewirausahaan Vol. 7, No. 2, Agustus 2013

Dian Ari Nugroho. 2017. Pengantar Manajemen untuk Organisasi Bisnis, Publik dan Nirlaba. Malang:UB Press.

Fiske, John.2012. Pengantar Ilmu Komunikasi, Jakarta : PT Rajagrafindo Persada

Ghozali, Imam. 2013. Aplikasi Analisis Multivariate dengan Program IBM SPSS

21 Update PLS Regresi. Semarang: Badan Penerbit Universitas Diponegoro.

Mulyana, Deddy. 2012. Ilmu Komunikasi Suatu Pengantar. Bandung: PT Remaja Rosdakarya

Nurmin, Arianto. 2018. Pengaruh Kepemimpinan Terhadap Kinerja dan Kepuasan Kerja Karyawan Pada PT. Gada Rajawali Dunia. Jurnal Jenius, UNPAM.

Vol.1 No.3. Diakses dari URL:

http://openjournal.unpam.ac.id/index.php/JJSDM/article/view/1289.

Nurmin, Arianto. 2019. Pengaruh Kepemimpinan dan Motivasi Terhadap Kinerja Karyawan. Jurnal Proceedings, UNPAM.Vol. 1 No. 1. Diakses dari URL: http://openjournal.unpam.ac.id/index.php/Proceedings/article/view/4247.

Nurmin, Arianto. 2020. Pengaruh Motivasi dan Lingkungan Kerja Terhadap Kinerja Karyawan. Jurnal Jenius, UNPAM. Vol. 3 No. 3. Diakses dari URL: http://openjournal.unpam.ac.id/index.php/JJSDM/article/view/4869. 
Pianda Didi. 2018. Kinerja Guru; Kompetensi Guru, Motivasi Kerja,

Kepemimpinan Kepala Sekolah. Sukabumi : CV Jejak, 2018

Stephen, Robbins. 2015. Perilaku Organisasi, Penerbit Salemba Empat, Jakarta.

Sugiyono. 2013. Metode Penelitian Pendidikan Pendekatan Kuantitatif, Kualitatif, dan R\&D. Bandung: Alfabeta.

Sugiyono. 2015. Metode Penelitian Kombinasi (Mix Methods). Bandung:

Alfabeta

Supardi. 2014. Kinerja Guru. Jakarta: PT. Raja Grafindo Persada.

Yukl, Gary .2015. Kepemimpinan Dalam Organisasi (Edisi 7). Jakarta : Indeks. 